\title{
PReS-FINAL-2134: Assessment of radiographic progression in patients (pts) with systemic juvenile idiopathic arthritis (sjia) treated with tocilizumab (TCZ): 2-year results from the tender trial
}

\author{
C Malattia', N Ruperto ${ }^{1}$, E Palmisani ${ }^{1}$, S Pederzoli', A Pistorio ${ }^{1}$, HI Brunner ${ }^{2}$, R Cuttica', I Calvo ${ }^{1}$, SM Garay ${ }^{1}$, \\ D Eleftheriou ${ }^{1}$, C Wouters ${ }^{1}$, J Wang ${ }^{3}$, C Devlin $^{3}$, D Lovell ${ }^{2}$, A Martini ${ }^{1}$, F De Benedetti ${ }^{4}$, A Ravelli i*, \\ PRCSG and PRINTO
}

From 20th Pediatric Rheumatology European Society (PReS) Congress

Ljubljana, Slovenia. 25-29 September 2013

\section{Introduction}

A phase 3 trial (TENDER) demonstrated the efficacy of the interleukin-6 receptor inhibitor TCZ in pts with sjia [1,2].

\section{Objectives}

To investigate progression of radiographic joint damage in pts with sjia treated with TCZ for up to 2 years in TENDER.

\section{Methods}

112 pts $2-17$ yrs old with active, refractory sjia of $\geq 6$ months' duration and inadequate response to previous non-steroidal anti-inflammatory drugs and oral corticosteroids were enrolled in TENDER. Pts were randomised 2:1 to receive TCZ according to body weight $(12 \mathrm{mg} / \mathrm{kg}$ $<30 \mathrm{~kg}$ or $8 \mathrm{mg} / \mathrm{kg} \geq 30 \mathrm{~kg}$ ) or placebo IV every 2 wks for 12 wks. Pts then received open-label TCZ in the ongoing long-term extension. Radiographic progression was calculated as change in adapted Sharp/van der Heijde score (ash) score and/or Poznanski score, assessed on hand and wrist radiographs, from baseline to wks 52 and 104. Radiographic progression was indicated by a positive ash score change or negative Poznanski score change. Clinical efficacy endpoints included American College of Rheumatology (ACR) Paediatric (Pedi) 70/90 responses.

1PRINTO, Genoa, Italy

Full list of author information is available at the end of the article

\section{Results}

Baseline and $\geq 1$ postbaseline ash and Poznanski scores were available for 47 and 33 pts, respectively (reasons for missing $\mathrm{x}$-rays: early withdrawal, no consent, unreadable $\mathrm{x}$-rays). Baseline characteristics for pts with radiographic data were similar to the whole TCZ population [1]. Pts with assessable ash/Poznanski scores had 5.2/4.8-yr disease duration, 21.3/19.2 active joints, 20.0/18.2 joints with limitation of movement and erythrocyte sedimentation rates of 53.9/59.2 mm/h. At wks 52 and 104, 20 and 19 pts, respectively, had ash progression, and 8 and 6 pts, respectively, had Poznanski score progression. Median change in ash score from baseline to wks 52 and 104 were 0 and 0.5 , respectively (Table). Median change in Poznanski score from baseline to wks 52 and 104 were 0.3 and 0.17 , respectively (Table 1 ).

\section{Conclusion}

Though changes in radiographic scores over time were seen in many pts, on average, pts with sjia did not experience

Table 1

\begin{tabular}{lcc}
\hline & Wk 52 & Wk 104 \\
\hline Ash score $(n=47)$, median (IQR) & $0.00(-8.70: 4.00)$ & $0.50(-7.50: 12.00)$ \\
\hline $\begin{array}{l}\text { Poznanski score }(n=33), \text { median } \\
\text { (IQR) }\end{array}$ & $0.30(-0.02: 1.03)$ & $0.17(0.01: 1.04)$ \\
\hline ACR Pedi $70(n=112), n / N(\%)$ & $92 / 106(86.8)$ & $57 / 65(87.7)$ \\
\hline ACR Pedi $90(n=112), n / N(\%)$ & $67 / 106(63.2)$ & $46 / 65(70.8)$ \\
\hline
\end{tabular}


noticeable progression of radiographic damage over 2 yrs of treatment with TCZ.

\section{Disclosure of interest}

C. Malattia: None declared., N. Ruperto Grant/Research Support from: Abbott, astrazeneca, BMS, Centocor, Lilly, Francesco Angelini, GSK, Italfarmaco, merckserono, Novartis, Pfizer, Regeneron, Roche, Sanofi Aventis, Schwarz Biosciences, Xoma, Wyeth, Consultant for: Abbott, astrazeneca, BMS, Centocor, Lilly, Francesco Angelini, GSK, Italfarmaco, merckserono, Novartis, Pfizer, Regeneron, Roche, Sanofi Aventis, Schwarz Biosciences, Xoma, Wyeth, Speakers Bureau: Abbott, Boehringer, BMS, Novartis, Astellas, Italfarmaco, medimmune, Pfizer, Roche, E. Palmisani: None declared., S. Pederzoli: None declared., A. Pistorio: None declared., H. I. Brunner Consultant for: Novartis, Genentech, medimmune, EMD Serono, AMS, Pfizer, UCB, Janssen, Speakers Bureau: Genentech, R. Cuttica Speakers Bureau: Roche, Abbott, Pfizer, Novartis, BMS, I. Calvo: None declared., S. M. Garay: None declared., D. Eleftheriou: None declared., C. Wouters: None declared., J. Wang Employee of: Roche Products Ltd, C. Devlin Employee of: Roche Products Ltd, D. Lovell Grant/Research Support from: NIH, Consultant for: astrazeneca, Centocor, Janssen, Wyeth, Amgen, Bristol-Meyers Squibb, Abbott, Pfizer, Regeneron, HoffmannLa Roche, Novartis, Genentech, Speakers Bureau: Roche, Genentech, A. Martini Grant/Research Support from: Abbott, astrazeneca, BMS, Centocor, Lilly, Francesco Angelini, GSK, Italfarmaco, merckserono, Novartis, Pfizer, Regeneron, Roche, Sanofi Aventis, Schwarz Biosciences, Xoma, Wyeth, Consultant for: Abbott, astrazeneca, BMS, Centocor, Lilly, Francesco Angelini, GSK, Italfarmaco, merckserono, Novartis, Pfizer, Regeneron, Roche, Sanofi Aventis, Schwarz Biosciences, Xoma, Wyeth, Speakers Bureau: Abbott, Boehringer, BMS, Novartis, Astellas, Italfarmaco, medimmune, Pfizer, Roche, F. De Benedetti Grant/Research Support from: Abbott, Pfizer, BMS, Roche, Novimmune, Novartis, SOBI, A. Ravelli: None declared.

Authors' details

${ }^{1}$ PRINTO, Genoa, Italy. ${ }^{2}$ PRCSG, Cincinnati, USA. ${ }^{3}$ Roche, Welwyn, UK. ${ }^{4}$ IRCCS

Ospedale Ped Bambino Gesu, Rome, Italy.

Published: 5 December 2013

\section{References}

1. De Benedetti F, et al: N Engl J Med 2012, 367:2385.

2. De Benedetti F, et al: Ann Rheum Dis 2012, 71(Suppl 3):425.

doi:10.1186/1546-0096-11-S2-P147

Cite this article as: Malattia et al:: PReS-FINAL-2134: Assessment of radiographic progression in patients (pts) with systemic juvenile

idiopathic arthritis (sjia) treated with tocilizumab (TCZ): 2-year results

from the tender trial. Pediatric Rheumatology 2013 11(Suppl 2):P147.

\section{Submit your next manuscript to BioMed Central} and take full advantage of:

- Convenient online submission

- Thorough peer review

- No space constraints or color figure charges

- Immediate publication on acceptance

- Inclusion in PubMed, CAS, Scopus and Google Scholar

- Research which is freely available for redistribution 